\title{
Upaya Meningkatkan Hasil Belajar Siswa Kelas VIII H SMPN 1 Cikoneng Melalui Metode Demonstrasipada Materi Pengukuran
}

\author{
Lili Alamin \\ SMP Negeri 1 Cikoneng Kecamatan Cikoneng Kabupaten Ciamis \\ Email : lilialamin15@gmail.com
}

\begin{abstract}
This research is based on the experience of researchers, found one class with the lowest learning achievement compared with other classes. only $50 \%$ of students whose daily test score reaches the minimum score of 70 . This shows that the learning has not been completed, therefore researchers try to improve students' learning outcomes in Physics Science lessons. The research method used is classroom action research. The subjects of the study were the students of class VIII H SMP Negeri 1 Cikoneng, Cikoneng District of Ciamis Regency with the number of students 32. Based on the results of action research using the demonstration method, it was found that the students' learning outcomes improved, as indicated by the increase of classical completeness in each cycle, in the first meeting reached an average of 62.74, the second meeting reaches an average of 70.63 , the third reaches an average of 74.38 , and the forth reach average of 78,13 . While for the students' learning completeness in the first meeting reach $56,25 \%$ or 15 students, second meeting reach $62,50 \%$ or 20 students, third meeting reach $75 \%$ or 24 student, and forth meeting reach $93,75 \%$ or 30 students. Thus it can be concluded that efforts to improve learning outcomes in the science of science Physics through demonstration methods using electronic media has been achieved.
\end{abstract}

\section{Keyword - Demonstration Method, Electronic Media, Measurement.}

Abstrak - Penelitian ini dilakukan berdasarkan pengalaman peneliti, ditemukan satu kelas yang prestasi belajarnya paling rendah dibandingkan dengan kelas yang lain. hanya 50\% siswa yang nilai ulangan hariannya mencapai kriteria ketuntasan minimal (KKM) sebesar 70. Hal ini menunjukkan bahwa pembelajaran belum tuntas, oleh karena itu peneliti berusaha meningkatkan hasil belajar siswa dalam pelajaran IPA Fisika. Metode penelitian yang digunakan adalah penelitian tindakan kelas (PTK). Subyek penelitian adalah siswa kelas VIII H SMP Negeri 1 Cikoneng Kecamatan Cikoneng Kabupaten Ciamis dengan jumlah siswa 32. Berdasarkan hasil penelitian tindakan dengan menggunakan metode demonstrasi, diperoleh bahwa hasil belajar siswa mengalami peningkatan, ditunjukkan dengan ditunjukkan dengan adanya peningkatan ketuntasan klasikal pada setiap siklusnya, yaitu pada siklus I pertemuan 1 mencapai rata-rata sebesar 62,74, siklus I pertemuan 2 mencapai rata-rata sebesar 70,63, siklus II pertemuan 1 mencapai rata-rata sebesar 74,38, dan siklus II pertemuan 2 mencapai ratarata 78,13. Sedangkan untuk ketuntasan belajar siswa pada siklus I pertemuan 1 mencapai 56,25\% atau 15 siswa, siklus I pertemuan 2 mencapai 62,50\% atau 20 siswa, 
siklus II pertemuan 1 mencapai 75\% atau 24 siswa, dan siklus II pertemuan 2 mencapai $93,75 \%$ atau 30 siswa. Dengan demikian dapat disimpulkan bahwa upaya peningkatan hasil belajar dalam pembelajaran IPA Fisika melalui metode demonstrasi menggunakan media elektronik telah tercapai.

\section{Kata Kunci : Metode Demonstrasi, Media Elektronik, Pengukuran.}

\section{Pendahuluan}

Ilmu Pengetahuan Alam (IPA) berkaitan dengan cara mencari tahu tentang alam secara sistematis, sehingga IPA bukan hanya penguasaan kumpulan pengetahuan berupa fakta-fakta, konsep-konsep atau prinsip-prinsip saja, melainkan juga merupakan suatu proses penemuan. Pendidikan IPA diharapkan menjadi wahana bagi peserta didik untuk mempelajari diri sendiri dan alam sekitar, serta prospek pengembangan lebih lanjut dalam menerapkannya di dalam kehidupan sehari-hari. Proses pembelajarannya menekankan pada pemberian pengalaman langsung untuk mengembangkan kompetensi agar menjelajahi dan memahami alam sekitar secara ilmiah. Pendidikan IPA diarahkan untuk inkuiri dan berbuat sehingga dapat membantu peserta didik untuk memperoleh pemahaman yang lebih mendalam tentang alam sekitar.

Materi pelajaran IPA Fisika kelas VIII semester ganjil terdiri dari materi Besaran dan Satuan, Gerak, Suhu dan Kalor serta Zat dan Wujudnya yang kesemuanya mencakup teori dan praktek. Di dalam SK dan KD yang tercantum dalam silabus, kompetensi yang diharapkan dapat dimiliki oleh siswa secara garis besarnya adalah kompetensi berpikir, bersikap dan bertindak ilmiah serta berkomunikasi. Oleh karena itu kompetensi merancang dan melakukan eksperimen merupakan kompetensi yang harus dimiliki oleh siswa di samping kompetensi dalam memahami konsep-konsep fisika.
Akan tetapi kenyataan di lapangan, penulis menemukan sebuah kendala, dimana sebagian besar siswa mengalami kesulitan pada materi pengukuran. Hasil belajar siswa cenderung selalu rendah. Hal ini bisa dilihat dari hasil belajar siswa kelas VIII $\mathrm{H}$ yang kurang memuaskan. Hanya 50\% atau 16 siswa dari 32 siswa yang mencapai nilai minimal sama dengan KKM sebesar 70. Pada saat membahas pengukuran panjang, peneliti memberikan potongan kertas karton yang sudah diukur dan ditentukan oleh peneliti nilai panjangnya terus siswa disuruh mengukurnya sendiri kemudian dikumpulkan, ternyata setelah diperiksa hasilnya $30 \%$ siswa mampu melakukan pengukuran panjang dengan benar, sedangkan $70 \%$ lainnya tidak mampu melakukan pengukuran panjang dengan benar. Penulis menanyakan permasalahan yang dialami siswa saat melakukan pengukuran panjang yang telah dilakukannya, ternyata $15 \%$ dari siswa yang tidak mampu melakukan pengukuran dengan benar, mengatakan tidak tahu cara pengukuran panjang dengan benar berkaitan dengan satuan pada alat ukur yang digunakan dan tidak memperhatikan saat penulis mendemonstrasikan cara melakukan pengukuran panjang. $80 \%$ dari siswa yang tidak mampu melakukan pengukuran dengan benar mengatakan tidak dapat mengukur panjang dengan benar dikarenakan saat penulis melakukan demonstrasi pengukuran panjang tidak dapat mengikuti apa yang didemonstrasikan karena mereka duduk di 
barisan tengah hingga barisan belakang, mereka sulit memperhatikan penunjukan skala dalam pengukuran saat penulis memberi contoh mengukur panjang sebuah benda dengan menggunakan mistar. Sedangkan 5\% lainnya dari siswa yang tidak dapat melakukan pengukuran panjang dengan benar mengatakan tidak dapat melakukan pengukuran dengan benar dikarenakan mereka tidak dapat menentukan nilai hasil pengukuran dengan ketelitian yang telah ditentukan, pada umumnya mereka merasa kesulitan saat ujung benda yang diukur tidak tepat berada pada skala mistar yang ditunjukkan.

Berdasarkan temuan di atas, penulis merasa bahwa kesulitan siswa pada materi pengukuran panjang akan menyebabkan kesulitan yang sama pada materi selanjutnya, yaitu pengukuran luas, volume dan massa jenis. Hal ini penulis yakini karena pada pengukuran luas dan volume benda dengan bentuk teratur menggunakan alat yang sama, sedangkan untuk pengukuran volume benda yang bentuknya tidak teratur dan pengukuran massa jenis menggunakan alat lainnya yaitu gelas berskala dan neraca.

Untuk pengukuran panjang sebuah benda diperlukan sebuah cara agar saat penulis mendemonstrasikan cara pengukuran benda tersebut dapat diamati oleh siswa dengan mudah dan jelas. Penulis mencoba melakukan metoda demonstrasi dengan dibantu media elektronik. Alat-alat tersebut digunakan untuk dapat menampilkan proses pengukuran yang dapat ditampilkan pada layar berukuran besar sehingga dapat diamati siswa dengan jelas walaupun oleh siswa yang duduk di barisan belakang.

Berdasarkan temuan di atas, penulis merasa tertarik dan termotivasi untuk melakukan Penelitian Tindakan Kelas (PTK) menggunakan metoda demonstrasi dengan dibantu media elektronik. Alat-alat tersebut digunakan untuk dapat menampilkan proses demonstrasi yang dapat ditampilkan pada layar berukuran besar sehingga dapat diamati siswa dengan jelas walaupun oleh siswa yang duduk di barisan belakang.

Berdasarkan latar belakang masalah yang dikemukan di atas, masalah yang dapat dirumuskan dalam penelitian ini adalah sebagai berikut :

1. Bagaimana peningkatan hasil belajar pada pembelajaran pengukuran melalui metode demonstrasi dengan menggunakan media elektronik pada siswa kelas VIII H SMP Negeri 1 Cikoneng Kecamatan Cikoneng?

2. Bagaimana penerapan metode demonstrasi dengan media elektronik pada pembelajaran pengukuran pada siswa kelas VIII H SMP Negeri 1 Cikoneng Kecamatan Cikoneng?

3. Apakah dengan menggunakan metode demonstrasi dapat pada media elektronik dapat meningkatkan hasil belajar siswa kelas VIII H SMP 1 Cikoneng Kecamatan Cikoneng?

Berdasarkan permasalahan tersebut, tujuan penelitian tindakan kelas ini adalah:

1. Untuk mengetahui peningkatan hasil belajar pada pembelajaran pengukuran melalui metode demonstrasi dengan menggunakan media elektronik pada siswa kelas VIII H SMP Negeri 1 Cikoneng Kecamatan Cikoneng.

2. Untuk mengetahui penerapan metode demonstrasi dengan media elektronik pada pembelajaran pengukuran pada siswa kelas VIII H SMP Negeri 1 Cikoneng Kecamatan Cikoneng.

3. Untuk meningkatkan penerapan metode demonstrasi dengan media elektronik pada pembelajaran pengukuran pada siswa kelas VIII $\mathrm{H}$ SMP Negeri 1 Cikoneng Kecamatan Cikoneng.

Manfaat yang diharapkan dari hasil 
Penelitian Tindakan Kelas (PTK) ini antara lain adalah :

\section{Bagi Guru}

- Meningkatkan kemampuan dalam memperbaiki

kualitas pembelajaran.

- Meningkatkan keterampilan dalam memilih dan menggunakan strategi pembelajaran.

- Menemukan strategi pembelajaran yang tepat, inovatif dan bervariatif.

- Menumbuhkan minat untuk melakukan penelitian dan berusaha mengembangkan diri sebagai guru professional

2. Bagi Siswa

- Meningkatkan daya tarik dan perhatian siswa terhadap konsep yang disajikan.

- Meningkatkan hasil belajar IPA Fisika.

3. Bagi Sekolah

- Meningkatkan kualitas pendidikan, khususnya pada mata pelajaran IPA Fisika di SMP Negeri 1 Cikoneng Kecamatan Cikoneng.

- Sebagai dokumentasi juga referensi perpustakaan sekolah dan diharapkan dapat dipergunakan sebagai bahan acuan untuk guru-guru mata pelajaran lain yang akan melaksanakan Penenlitian Tindakan Kelas (PTK).

\section{Metode Penelitian}

\section{A. Setting dan Subjek Penelitian}

Penelitian tindakan kelas dilaksanakan di SMP Negeri 1 Cikoneng Kecamatan Cikoneng, yang beralamat di Jalan Raya Margaluyu No. 9 Kecamatan Cikoneng Kabupaten Ciamis dengan status Negeri dan Nomor NSS/NPSN $201021402008 / 20211637$.
Subjek penelitiannya adalah siswa kelas VIII H SMP Negeri 1 Cikoneng Kecamatan Cikoneng yang berjumlah 32 siswa laki-laki.

Pelaksanaan penelitian dilaksanakan selama 3 bulan, yaitu dari bulan Maret sampai bulan Mei 2016, semester genap tahun pelajaran 2015/2016. Adapun waktunya sebagai berikut:

1. Persiapan penelitian tanggal 3 s.d 16 Maret 2016

2. Pelaksanaan penelitian sebagai berikut:

- Siklus I pertemuan 1 dilaksanakan tanggal 6 April 2016,

- Siklus I pertemuan 2 dilaksanakan tanggal 13 April 2016,

- Siklus II pertemuan 1 dilaksanakan tanggal 20 April 2016,

- Siklus II pertemuan 2 dilaksanakan tanggal 27 April 2016 ,

3. Pengolahan dan penggandaan hasill penelitian tanggal 2 s.d 16 Mei 2016

4. Seminar hasil penelitian tanggal 21 Mei 2016

5. Pelaporan hasil penelitian tanggal 26 Mei 2016

\section{B. Prosedur Penelitian}

Prosedur penelitian terdiri dari tahap perencanaan, tahap pelaksanaan, tahap observasi, dan tahap refleksi.

\section{Teknik Pengumpulan Data}

1. Siswa sebagai sumber data hasil belajar yang berupa data kuantitatif

2. Guru sebagai sumber data keterlaksanaan pembelajaran berupa data kualitatif.

\section{Teknik Analisis Data}

Data yang diperoleh akan dianalisis secara deskriptif, ditentukan persentase masing-masing indicator keberhasilan 
yang telah ditetapkan. Hasil belajar siswa: dianalisis apakah jumlah siswa yang memperoleh nilai mencapai KKM untuk kompetensi yang diujikan telah menunjukkan ketercapaian indicator keberhasilan atau belum.

Hasil belajar siswa telah mencapai indikator keberhasilan apabila $75 \%$ dari seluruh siswa telah mencapai prestasi belajar minimal sama dengan KKM sebesar 70 .

Hasil belajar siswa ditentukan dengan cara berikut :

Nilai $=\frac{\text { Esoal yang dijawab benar }}{\text { Ejumlah soal }} \times 100$

(skala 0-100)

(Arifin, 2009: 232)

Ketuntasan secara klasikal dihitung dengan menggunakan rumus:

Ketuntasankelas

$=\frac{\sum \text { siswa yang mencapai KKM }}{\sum \text { siswa yang mengikuti tes }} \times 100 \%$

Keterlaksanaan metode demonstrasi menggunakan media elektronik dipresentasekan komponen yang terpenuhi terhadap seluruh komponen yang seharusnya terlaksana.

\section{E. Indikator Keberhasilan}

Tolak ukur keberhasilan penelitian ini :

Bila 75\% dari seluruh siswa telah mencapai hasil belajar minimal sama dengan KKM sebesar 65. (Mulyasa, 2004: 102)

\section{Hasil PENELITIAN DAN PEMBAHASAN}

\section{A. Keterlaksanaan Hasil Observasi}

Seluruh dokumen harus diketik dalam fontaTimes New Roman, dengan acuan ukuran teks terlihat pada Tabel 1.
Dari deskripsi data yang diperoleh maka dapat dibahas dari hasil penelitian dari siklus I dan siklus II diperoleh deskripsi data seluruh siklus hasilnya dapat dilihat di bawah ini:

1. Aktivitas Guru

Berdasarkan hasil temuan observer pada siklus I pertemuan 1 diperoleh hasil 69,23\% menyatakan sudah baik dalam melaksanakan pembelajaran sesuai dengan rencana pembelajaran dan $30,77 \%$ belum sesuai dalam rencana pembelajaran. Pada siklus I pertemuan 2 diperoleh hasil $84,61 \%$ menyatakan sudah baik dalam melaksanakan pembelajaran sesuai dengan rencana pembelajaran dan $15,39 \%$ belum sesuai dalam rencana pembelajaran. Pada siklus II pertemuan 1 diperoleh hasil 92,31\% menyatakan sudah baik dalam melaksanakan pembelajaran sesuai dengan rencana pembelajaran dan $7,69 \%$ belum sesuai dalam rencana pembelajaran. Pada siklus II pertemuan 2 diperoleh hasil bahwa secara keseluruhan (100\%) proses pembelajaran yang dilakukan oleh guru dinyatakan sudah baik sesuai dengan rencana pembelajaran.

Gambar 1. Grafik Hasil Pengamatan Aktivitas Guru

b. Aktivitas Siswa

Berdasarkan pengamatan peneliti dan observer selama mengamati pembelajaran dengan menggunakan metode demonstrasi pada materi pengukuran hal-hal yang teramati oleh observer adalah kegiatan memperhatikan penjelasan guru pada siklus I pertemuan 1 mencapai presentase $53,13 \%$ atau 17 orang siswa, pada siklus I pertemuan 2 mencapai presentase $62,50 \%$ atau 20 orang siswa, pada siklus II pertemuan 1 mencapai presentase $68,75 \%$ atau 22 orang siswa, dan pada siklus II 
pertemuan 2 mencapai presentasi sebesar $81,25 \%$ atau 26 orang siswa.

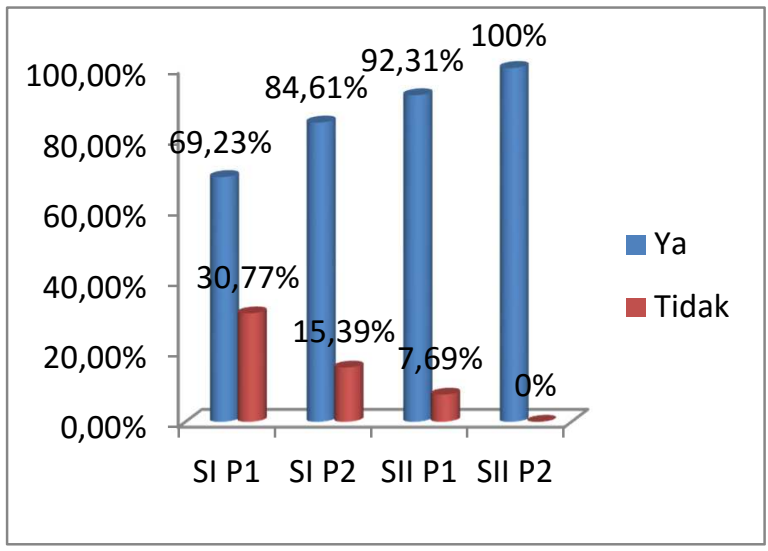

Gambar 2. Grafik Hasil

Pengamatan Aktivitas Guru

Berdiskusi atau bertanya pada siklus I pertemuan 1 mencapai presentase $34,38 \%$ atau 11 orang siswa, pada siklus I pertemuan 2 mencapai presentase $43,75 \%$ atau 14 orang siswa, pada siklus II pertemuan 1 mencapai presentase $56,25 \%$ atau 18 orang siswa, dan pada siklus II pertemuan 2 mencapai presentasi sebesar $65,63 \%$ atau 21 orang siswa.

Keberanian mengemukaan pendapat pada siklus I pertemuan 1 mencapai presentase sebesar 37,50\% atau 12 orang siswa, pada siklus I pertemuan 2 mencapai presentase $46,88 \%$ atau 15 orang siswa, pada siklus II pertemuan 1 mencapai presentase $59,38 \%$ atau 19 orang siswa, dan pada siklus II pertemuan 2 mencapai presentasi sebesar 71,88\% atau 23 orang siswa.

Berani tampil di depan kelas dalam mempersentasikan hasil belajar pada siklus I pertemuan 1 mencapai persentase sebesar $31,25 \%$ atau 10 orang siswa, pada siklus I pertemuan 2 mencapai presentase $40,63 \%$ atau 13 orang siswa, pada siklus II pertemuan 1 mencapai presentase $53,13 \%$ atau 17 orang siswa, dan pada siklus II pertemuan 2 mencapai presentasi sebesar $62,50 \%$ atau 20 orang siswa.

Mengerjakan evaluasi secara sungguh-sungguh pada siklus I pertemuan 1 mencapai persentase sebesar $50 \%$ atau 16 orang siswa, pada siklus I pertemuan 2 mencapai presentase $56,25 \%$ atau 18 orang siswa, pada siklus II pertemuan 1 mencapai presentase $65,63 \%$ atau 21 orang siswa, dan pada siklus II pertemuan 2 mencapai presentasi sebesar $78,13 \%$ atau 25 orang siswa.

TABEL 1

REKAPITULASI AKTIVITAS SISWA SELAMA PEMBELAJARAN SIKLUS I DAN SIKLUS II

\begin{tabular}{|c|c|c|c|c|c|}
\hline \multirow{2}{*}{$\begin{array}{c}\text { SikI } \\
\text { uS }\end{array}$} & \multicolumn{5}{|c|}{ Aspek yang diamati } \\
\cline { 2 - 6 } & A & B & C & D & E \\
\hline S I & $\mathbf{5 3 , 1}$ & $\mathbf{3 4 , 3}$ & $\mathbf{3 7 , 5}$ & $\mathbf{3 1 , 2}$ & $\mathbf{5 0 , 0}$ \\
/P1 & $\mathbf{3 \%}$ & $\mathbf{8 \%}$ & $\mathbf{0 \%}$ & $\mathbf{5 \%}$ & $\mathbf{0 \%}$ \\
\hline S I & $\mathbf{6 2 , 5}$ & $\mathbf{4 3 , 7}$ & $\mathbf{4 6 , 8}$ & $\mathbf{4 0 , 6}$ & $\mathbf{5 6 , 2}$ \\
/P2 & $\mathbf{0 \%}$ & $\mathbf{5 \%}$ & $\mathbf{8 \%}$ & $\mathbf{3 \%}$ & $\mathbf{5 \%}$ \\
\hline S II & $\mathbf{6 8 , 7}$ & $\mathbf{5 6 , 2}$ & $\mathbf{5 9 , 2}$ & $\mathbf{5 3 , 1}$ & $\mathbf{6 5 , 6}$ \\
/P1 & $\mathbf{5 \%}$ & $\mathbf{5 \%}$ & $\mathbf{8 \%}$ & $\mathbf{3 \%}$ & $\mathbf{3 \%}$ \\
\hline S II & $\mathbf{8 1 , 2}$ & $\mathbf{6 5 , 6}$ & $\mathbf{7 1 , 8}$ & $\mathbf{6 2 , 6}$ & $\mathbf{7 8 , 1}$ \\
/P2 & $\mathbf{5 \%}$ & $\mathbf{3 \%}$ & $\mathbf{8 \%}$ & $\mathbf{0 \%}$ & $\mathbf{3 \%}$ \\
\hline
\end{tabular}

Keterangan :

A. Memperhatikan penjelasan guru

B. Berdiskusi atau bertanya jawab dengan teman dalam kelompok

C. Keberanian mengemukakan pendapat

D. Berani tampil di depan kelas, mempresentasikan hasil pekerjaanya

E. Mengerjakan evaluasi secara sungguh-sungguh

Berdasarkan pembahasan dari hasil penelitian bahwa pada penelitian tindakan kelas aktivitas siswa dapat meningkat dari setiap siklus.

Keterangan :

A. Memperhatikan penjelasan guru 
B. Berdiskusi atau bertanya jawab dengan teman dalam kelompok

C. Keberanian mengemukakan pendapat

D. Berani tampil di depan kelas, mempresentasikan hasil pekerjaanya

E. Mengerjakan evaluasi secara sungguh-sungguh

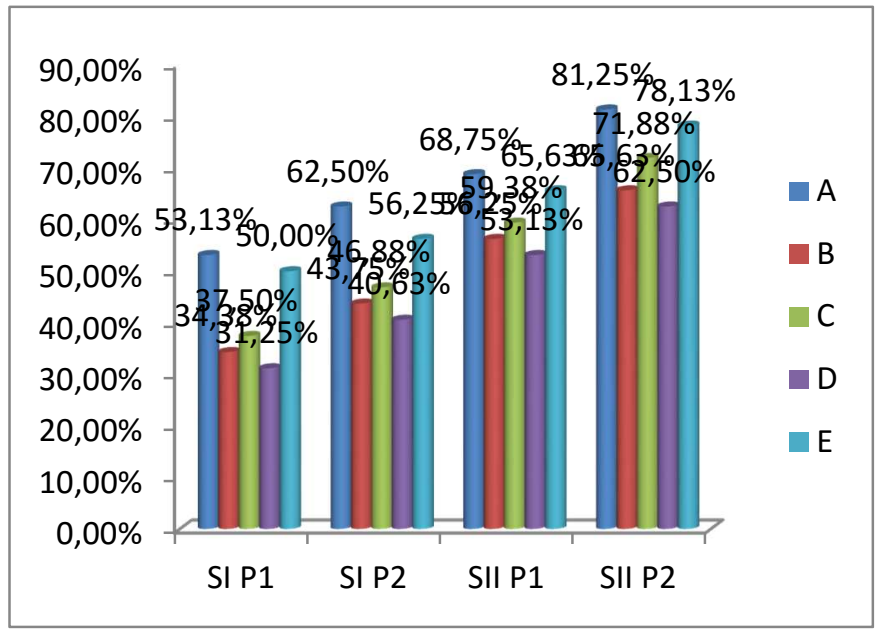

Gambar 2. Grafik Hasil Pengamatan Aktivitas Siswa Selama Pembelajaran

\section{B. Keterlaksanaan Belajar}

Keterlaksanaan proses pembelajaran dengan menggunakan metode demonstrasi pada setiap siklus dalam penelitian ini mengalami kenaikan yaitu siklus I pertemuan 1 baru 56,25\% (18 orang dari 32 siswa) yang nilainya sudah memenuhi KKM sebesar 65 dari $75 \%$ yang diharapkan. Artinya masih terdapat minimal $43,75 \%$ siswa yang belum memenuhi KKM. Dan rata-rata kelas baru mencapai 70,63. Hal ini disebabkan belum semua langkah KBM dilaksanakan dengan baik oleh guru. Pada siklus I pertemuan 2 ketuntasan belajar mencapai $62,50 \%$ (20 siswa dari 32 siswa) yang nilainya sudah memenuhi KKM sebesar 65. Dari $75 \%$ yang diharapkan artinya masih terdapat minimal $37,50 \%$ siswa yang belum memenuhi KKM dan rata-rata kelas mencapai 74,38. Pada siklus II pertemuan
1 ketuntasan belajar meningkat menjadi $75 \%$ (24 siswa dari 32 siswa) yang nilainya sudah memenuhi KKM sebesar $65 \%$ yang diharapkan artinya masih terdapat minimal $25 \%$ siswa yang belum memenuhi KKM. Sedangkan rata-rata kelas mencapai 74,38. Di bandingkan dengan siklus I pertemuan 2 dengan rata-rata 70 menunjukan adanya peningkatan sebesar 3,75\%. Dan pada siklus II pertemuan 2 ketuntasan belajar sudah mencapai $93,75 \%$ (30 siswa dari 32 siswa) yang nilainya sudah memenuhi KKM sebesar 65 yang diharapkan dan tidak tuntas sebanyak 6,25\%, Perbandingan peningkatan hasil belajar siklus II pertemuan 1 dengan rata-rata 74,38 dan siklus II pertemuan 2 yaitu 78,13 , maka ada peningkatan 3,75 .

\section{Ketuntasan Belajar}

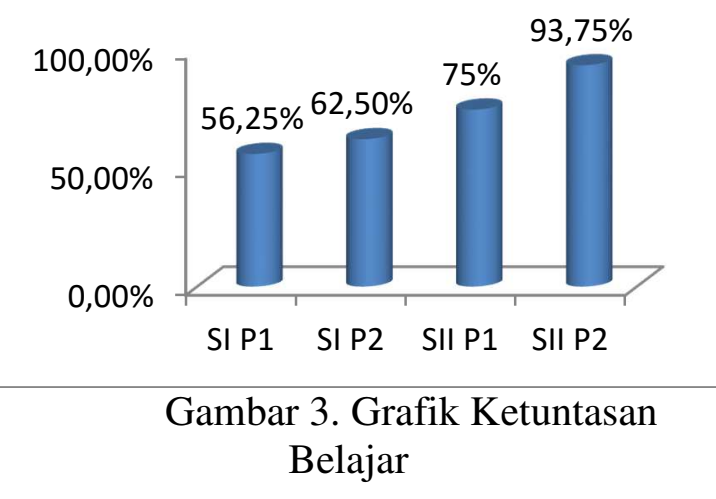

Melihat grafik hasil penelitian di atas maka terjadi kenaikan keterlaksanaan pembelajaran dalam ketuntasan belajar, yaitu $6,25 \%$ dari siklus I pertemuan $1 \mathrm{ke}$ siklus I pertemuan $2,12,50 \%$ dari siklus I pertemuan 2 ke siklus II pertemuan 1, $18,75 \%$ dari siklus II pertemuan 1 ke siklus II pertemuan 2 . 


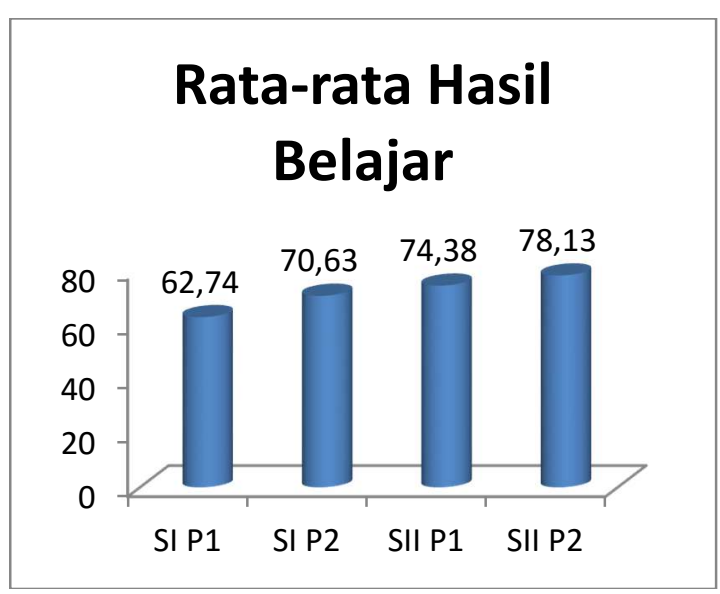

Gambar 4. Grafik Rata-Rata Hasil Belajar

Melihat grafik hasil rata-rata hasil tes belajar di atas maka terjadi kenaikan ratarata hasil belajar siswa, yaitu rata-rata 7,88 dari siklus I pertemuan 1 ke siklus I pertemuan 2 , rata-rata 3,75 dari siklus I pertemuan 2 ke siklus II pertemuan 1, ratarata 3,75 dari siklus II pertemuan $1 \mathrm{ke}$ siklus II pertemuan 2 .

Mengingat proses pembelajaran antar siklus dapat meningkat maka tindakan selanjutnya dihentikan karena sudah mencapai hasil ketuntasan belajar maksimal $85 \%$. Namun masih ada siswa yang nilaianya dibawah ketuntasan belajar sekitar $6,25 \%$ atau 2 orang.

\section{KESIMPULAN DAN SARAN}

Berdasarkan lembar observasi dan hasil analisis data terhadap hasil tes, maka dapat dibuat kesimpulan sebagai berikut:

1. Keterlaksanaan pembelajaran dengan menggunakan metode demonstrasi pada siswa kelas VIII H SMP Negeri 1 Cikoneng Kecamatan Cikoneng mengalami peningkatan pada setiap siklusnya, kenaikan keterlaksanaan pembelajaran dalam ketuntasan belajar, yaitu $6,25 \%$ dari siklus I pertemuan 1 ke siklus I pertemuan 2 , $12,50 \%$ dari siklus I pertemuan $2 \mathrm{ke}$ siklus II pertemuan 1, $18,75 \%$ dari siklus II pertemuan 1 ke siklus II pertemuan
2. Penerapan metode demonstrasi pada pembelajaran pengukuran dapat meningkatkan hasil belajar siswa kelas VIII H SMP Negeri 1 Cikoneng Kecamatan Cikoneng yang ditunjukkan dengan adanya peningkatan ketuntasan klasikal pada setiap siklusnya, yaitu rata-rata 7,88 dari siklus I pertemuan 1 ke siklus I pertemuan 2, rata-rata 3,75 dari siklus I pertemuan 2 ke siklus II pertemuan 1 , rata-rata 3,75 dari siklus II pertemuan 1 ke siklus II pertemuan 2 .

3. Keterlaksanaan pembelajaran dan ketuntasan klasikal tercapai pada siklus ke II pertemuan 2 .

Berdasarkan hasil penelitian serta kesimpulan yang diperoleh, maka terdapat beberapa saran yang dapatdikemukakan untuk penelitian lebihlanjut, diantaranya:

1. Pembagian kelompok diusahakan kurang dari 5 siswa perkelompok.

2. Benda-benda yang diukur diusahakan benda-benda yang berada di sekitar lingkungannya agar lebih menarik.

3. Penghargaan untuk siswa atau kelompok diusahakan berupa benda yang bermanfaat, seperti buku tulis dan pulpen.

\section{Daftar Pustaka}

[1] Departemen Pendidikan Nasional, 2005 Penelitian Tindakan Kelas (Bahan Pelatihan To T PTBK), Jakarta, Direktorat Jenderal Pendidikan Dasar dan Menengah, Direktorat Pendidikan Lanjutan Pertama

[2] Hartadi, Titut, 2010, Pedoman Penelitian Tindakan Sekolah \& Kelas, Karawang, Sehati Media.

[3] Mulyasa, E. (2004) .Implementasi Kurikulum 2004, Panduan Pembelajaran KBK. Bandung: Rosda [4] Save, M.D (2005), Kamus Besar Ilmu Pengetahuan, Cetakan keempat. Jakarta, 
p-ISSN : 2460-7363

e-ISSN : 2614-6606

Lembaga Pengkajian Kebudayaan Nusantara

[5] Sudjana, N (2010), Dasar Dasar Proses Belajar Mengajar, Bandung : Sinar Baru Algesindo

[6] Sumiati dan Asra (2007, Metode Pembelajaran, Bandung : CV Wacana Prima

[7] Universitas Pendidikan Indonesia, 2009, Pedoman Penulisan Karya Ilmiah, Bandung, Universitas Pendidikan Indonesia 